\title{
Sport as a Means for Reducing the Cost of Illness - Some Theoretical, Statistical and Empirical Remarks
}

\author{
GERT G. WAGNER
}

Max-Planck-Institut für Bildungsforschung, Lentzeallee 94, 1000 Berlin 33, Fed. Rep. of Germany*)

\section{Abstract}

In the Federal Republic of Germany, many supporters of the sports movement (Sportbewegung) suggest that sport might be an effective and efficient instrument to reduce the costs of illness and death. In this paper empirical evidence is given on the basis of economic theory to support the argument that sport would not be a superior instrument for cost reduction. The main reason is that instrumental sport may not lead to better health in every case. Secondly, the opportunity costs of sport practicing are distributed unequally. Thirdly, it is probable that better health and an increased life expectancy would not reduce expenditure of goods and services for health care. To learn more about the epidemiological links between instrumental sport and health, an improved kind of longitudinal data would be necessary.

\section{Introduction}

In the Federal Republic of Germany as well as in many other Western nations, the burden of the expenditures for medical care is growing. With this in mind, the German sports movement (Sportbewegung), especially the German Sport Federation (DSB) is considering whether an increase of sport activities might be an instrument to reduce illness, raise life expectancy and decrease health care costs. On the basis of an estimate of 275 billion of Deutschmarks for total costs of illness and death in 1980, Mellerowicz and Dürrwächter developed a reform proposal $(1983,1985)$ for the statutory health insurance system, which would establish incentives for sport activities by means of a bonus system.

This paper ${ }^{1}$ deals first with the theoretical background developed by economists to measure total costs of illness and death. Secondly, the empirical evindence of the influence of sport activities on health will be reviewed. Thirdly, it will be analyzed whether a better health status of the population would reduce the health care expenditure assuming no change in the structure of the supply side of the health care system.

\footnotetext{
* The author is grateful to Rainer W. Christ, Roland Eisen, Christa Fricke, Christof Helberger, Helmut Knepel, Werner W. Pommerehne, Brigitte PreißI, Hans-Gerd Sack, Hilmar Schneider, Ulrike Schöbel, Constance Allan-Witte, Peter Zweifel and the contributers of the second workshop "Sports Economics" (held in Berlin 1986) for many discussions of an earlier version of this paper. The author is responsible alone for any remaining errors.
} 
In this paper a possible economic effect of sport, which might be the result of sport activities and labor productivity, is not investigated. On the other hand, the costs of injuries caused by sport activities as well as the costs for sport facilities are not taken into consideration. Neither is the cultural dimension of sport taken into account (cf. Pommerehne and Frey 1985). This paper will only outline the framework of further research and draw attention to various aspects of the problem.

The paper deals with leisure sport activities only; professional sport is left out It is important to emphasize that the traditional motivation of sportsmen ist not an instrumental one (cf. Lenk 1985; Rittner 1985), in the sense of using sport as at means of improving one's health.

\section{Economic Theory of Health Costs}

In the discussion of the costs of health and illness two kinds of costs are important: monetary costs of health care and social costs, which result from years of enjoyable life lost due to illness. In order to estimate the disutility of these kinds of costs, it is necessary to explore human behavior.

We behave in an environment of scarce resources; this is true for goods and services as well as for our own time. This means that a special kind of expenditure (e.g. health care goods and services) and a special kind of behavior (e.g. jogging as a way of becoming more healthy) have opportunity costs because they preclude other kinds of desired expenditure and behavior. It is extreme to believe that a long life and good health would be goals which are valuable to such an extent that a well informed person would behave in a manner maximizing his/her life expectancy. There is no way to avoid the implicite optimization process which balances various kinds of behavior supporting or attacking our health capital (cf. McKenzie and Tullock 1978). To make this obvious, let us suppose we could spend all our time and all our goods and services on improving our health. It is evident that even this extreme case must be considered if we try to avoid one kind of illness (e.g. psychic problems) or another kind of illness (e.g. heart disease).

Thus, the present structure of the health care system is inefficient in principle because there is no explicit optimization of health care expenditure. On the other hand, it is obvious that the health care expenditure does not create disutility in total, because it is rational to substitute time necessary for preventive behavior by goods and services of the health care system. This result leads to another important conclusion: the economic value of life span which might be gained through sport is not the value of money and wealth which could be earned in additional life years but the value is only the willingness-to-pay for a longer life. The value of gained years is the value of time and expenditures necessary to prolong the life span. With regard to the necessary time, we will refer in the following to the willingness-to-spend.

Three empirical questions are important for the willingness-to-spend more time for a longer life: (1) Are the death probabilities relatively high or low? (2) Is the probability of survival high or low, if one spends time to practice sport as a means of becoming healthier and living longer? (3) What are the determinants of 
se value of time. First empirical answers to these questions are given below in sction 4.

The hitherto theoretical arguments and answers were found for a perfect orld, where no information problems exist and no social costs appear. But the :al world is not perfect in this sense. Three problems are important: information not complete, there are barriers to entering special markets and the structure of ie statutory health insurance system in the Federal Republic of Germany romote in principle moral hazard, i.e. social costs.

It is obvious that there is a lack of information about the causalities between sort, health and life expectancy. It is true too, that the possibilites to engage in ort are distributed unequally, especially regarding education and sport icilities ${ }^{2}$. More empirical evidence is given in the next section.

The structure of the statutory health insurance system of the Federal Republic f Germany is characterized by contribution payments which are collected by a ayroll tax which is not actuarially fair. This is true too, because there exists no coIsurance or bonus system which could be instruments to create an ex post kind of ztuarial fairness and to minimize moral hazard. Many economists argue that this ructure is a strong incentive to consume health goods and services in an tefficient manner (free rider problem), i.e. there exist social costs (cf. Coase 761). A special type of social costs is created because people who waste their ealth capital are not fully responsible for the resulting health care costs. At this oint Mellerowicz and Dürrwächter introduce their argument: they propose an stuarially fair contribution scheme to avoid moral hazard and to minimize costs f health care and social costs of illness and death.

But the question is, what is the price of an actuarial contribution scheme? The nswer depends on information and transaction costs being created by a ifferentiated payroll tax and/or by a bonus system for the statutory health Isurance system. This is an empirical question too, and an answer is given at the nd of the next section.

\section{. Statistical Problems}

is obvious that the causalities between sport practice, health and death are ecisive for the answers to most of the questions raised in section 2 . This section is evoted to some fundamental statistical problems which are concerned with rrecasts based on statistical inference, i.e. problems caused by unobserved eterogenity and sample selection bias.

Let us first examine the typical empirical studies which allow conclusions about zort practice and health. Most of the studies known by the author are studies hich are based on a special selection of people, i.e. a subsample of people who Iccessfully and happily practice sport on a voluntary base. There are many zasons why such a subsample of sportsmen is a special selection of the whole opulation, because the utility those people gain from sport practice is higher an the potential utility of the still non-active persons. Thus, the probability is ery high that we will have a sample selection bias (cf. Heckmann 1979) if we try s forecast the consequences of sport activities on utility, health and survival 
probability of presently inactive people on the basis of the observed figures of sportsmen.

Something else indicates that this forecast would be very complicated: the explained variance of health status and death probabilities is considerably small. It is not higher than 20 to 30 percent, which is well known for most cross-sectional studies in social sciences. The special sample selection problem outlined above and our common knowledge indicate that a small fraction of unexplained variance are indicators for relevant, however unobserved variables ${ }^{3}$. This means that it is not generally possible to make predictions in the sense that the consequences of a change in behavior may be the same consequences which have been observed for those people who already behave on a voluntary basis in the intended manner (cf. Daganzo 1979, p. 121).

It is also well known from epidemiological studies, that the unobserved heterogenity of death causes has a special structure, i.e. we know that the risk factors of death are competing risks (cf. Vaupel and Yashin 1985). Competing risks mean that it is not trivial to estimate the gain of life years if we could eliminate a special cause of death, e.g. heart diseases. This is true because another cause of death, e.g. cancer, which previously did not lead to the death of a person, might now be successful. Consequently, it is probable that the computations overstated the lost years by a special death cause.

\section{Empirical Evidence}

In this section empirical evidence is given for four questions

- What is the relative valuation of death probability?

- Can sport ensure that a person becomes healthier or lives longer?

- What are the opportunity costs of sport practice?

- Would incentives for sport activities be an efficient instrument to reduce health care costs?

It is a common experience that our valuation of disutility which may occur from risks with a low probability is much lower than the valuation of very risk:! activities (cf. Pelzmann 1985, p. 31). This is a strong indicator that our discount rate for disutility of an early death is very high because in Western countries the overall death probabilities are less than one percent per year till the age of 50 years and older. It would be necessary to do special empirical work to answer the question if the risk perception and valuation varies between persons or social groups. If so, it would be an indicator for the distribution of social costs caused by unvoluntary behavior which attacks health capital.

The next question is whether sport practicing (instrumentalized for health fostering purposes only) could lower death probability to a considerable extent? We have representative evidence from surveys only comparing the consequences of voluntary sport activities vs. non sport activities. The study of Paffenbarger $\mathrm{ct}$ al. (1986) may be the best of many studies done all over the world. Paffenbarger at al. observed more than 10,000 Harvard alumni (from 1920 to 1955) in a longitudinal study. Paffenbarger et al. control for sample selection of the initial population, i.e. they exclude the data from people who did not practice as students due to health problems. 
As a result Paffenbarger et al. find that sport activities, especially jogging, icrease the overall life expectancy of sportsmen by two years. But this is only the zsult for people who practice on a voluntary basis. It is small increase compared , eight years estimated gain of years by Henke (1985), applying a conventional :atistical method which calculates the deletion of one cause of death (here: heart iseases) for survival probabilities.

The differences between Henke's and Paffenbarger's results are due to ifferences of the populations (United States vs. West Germany; well educated nd trained people vs. entire population), but the small gain of the observed two ears is mainly a result of unobserved heterogenity and the competing risk roblems pointed out in section 3. Because it is known (cf. Vallin 1980) that well ducated and skilled people have a higher life expectancy than less educated and illed people, the observable gain of life years may be higher for an entire opulation of men and women practicing sports on a voluntary base.

But it is true too, that the differences of life expectancy for other break downs, specially when social classes and/or occupational differences are considered, are $n$ the average significantly higher than those between observed sportsmen and on-sportsmen. For example: in the United States, the United Kingdom. France nd Finland the difference of further life expectation for a 35 years old unskilled 'orker and a teacher amounts to approximately eight years (cf. Proebsting 1984. Vagner 1984, pp. 173). To a considerable degree, this might be the result of ifferent sport practices, but it is very unlikely that the entire difference of eight ears can be explained by the sport factor only.

No conclusive prediction can be made to support the idea that sport, which was litiated as a means of improving health, would be successful in every single case. his is true due to the competing risk problem again, but it is also true due to the istress that arises when people are not happily engaged in sport (cf. Rittner 785). Statisfaction is an important point too, because Hollman et al. (1985) find ut that only some specific kinds of sport have direct positive effects on the bjective indicators of health status. It is not surprising that jogging is most aluable, however, table tennis, squash, golf and even skiing do not have gnificant effects!

Thus, it is not surprising that many people do not engage in sport. If someone oes not enjoy practicing, the overall value of timespending on sport is very low. port as an instrument of health prevention has the same problem as other istruments of prevention. Prevention makes a very uncertain prediction and revention demands activities which are often not enjoyable (cf. Schnocks 1985, $.120)$.

The next question is whether the opportunity costs of time spent on sports are istributed equally. If not, it would make distributional problems if incentives for jort practicing were set by the health insurance system. In economic theory, it is nclear whether the time costs of individuals with low or high wage rates were low $r$ high. But a look at the empirical evidence tells us - for the Federal Republic of iermany in 1980 - that overtime work is observed far often at a low wage rate (cf. ialler and Wagner 1983), i.e. the opportunity cost of non-leisure time is higher Ir low earners than for high income earners. The same phenomena of so called me-poor people is pointed out for the United States, too (cf. Vickrey 1977). 
At least for the Federal Republic of Germany, unskilled people have higher barriers to the "sports market" than skilled people. This is a result of the distribution of sport facilities, and a result too, of the education of people. In fact, it is well known that unskilled workers, women, immigrants and unemployed people have low participation rates in sport activities (cf. Dürrwächter and Mellerowicz 1983). The conclusion is unequivocal: if the health insurance system would establish incentives for sport practicing specific groups would not profit, but would lose in terms of opportunity costs for timespending in sports.

If we ignore those problems at present, the remaining question is whether efficient instruments are possible to set incentives that would encourage people to become healthier by participating in sports.

One possibility would be an ex ante premium scheme of the statutory health insurance system which differentiates between specific sportsmen/women and non-sportsmen/women (cf. for an analogous proposal Stockes 1983). But it is well known by actuarists that premium schemes are inefficient when combined with variables of uncertain effects. Nobody could say which type of sport would be optimal for a specific person. It would also be costly to control those activities. In fact there is no private health insurance company known which differentiates the premiums by sport activities.

Co-insurances, deductibles and bonus systems are well known instruments of private insurance companies to avoid moral hazard (cf. Waser and Zweifel 1986). A bonus system could be practiced to reward a good health status. As a result, people who are not responsible for their bad health status, e.g. disabled, handicapped or even blue collar workers who have not had a chance to get in good shape, would be sanctioned by a bonus system. It should be clear at this point that it would be impossible or at least expensive to try to disentangle the causes of bad health status.

Thus, the introduction of systematically effective bonus systems in a statutory health insurance system would attack the foundation of a compulsory insurance system, because a bonus scheme would attack social cohesion.

\section{Consequences for the Estimation of Costs of Illness and Death}

For the Federal Republic of Germany, Dürrwächter and Mellerowicz estimated 275 billion Deutschmarks to be the cost of illness and death in 1980. A comparable estimate of Henke (1985) finds a confidence interval of approximately 100 billion DM. Henke's estimate is much better documented than Dürrwächter and Mellerowicz's figures. Thus the following statements refer to Henke's work, which represents the current state of the art (cf. Hodgson 1983).

However, due to a lack of appropriate data, Henke cannot use the willingnessto-pay method for the estimation of the social costs of illness and death. He must use the so called human capital approach, which calculates the costs by a simple valuation of lost life years by their earnings capacity. Within this method Henke overestimates the social costs, because he must use estimated gains of life years and not observed ones. Henke as well as others knows that estimated figures are higher than observable years. As a result, we must correct Henke's results 
ownwards and the remaining social costs of bad health status (measured as uman capital losses), which might be a result of heart diseases, may amount to 10 illion DM with a confidence intervall, which is greater than this number. A more nportant result of Henke is the fact that social costs of illness and death caused y heart disease are relatively low because heart disease occurs typically late in ie life cycle.

Because of the simple life-valuation, which is based on the human capital pproach, Henke uses other indicators for the valuation of illness and death, too. hese indicators give no money-equivalent, but they may reflect other disutility lements of death. One of these indicators is the loss of years per capita by ifferent causes of death. It is shown in figure 1 that this indicator is very high, not ue to causes which might be attacked by sport activities, but instead due to other auses of death which are relevant for young people. Problems of pregnancy and hild mortality, as well as injuries (like car accidents) are causes of death which annot be avoided by sport practicing.

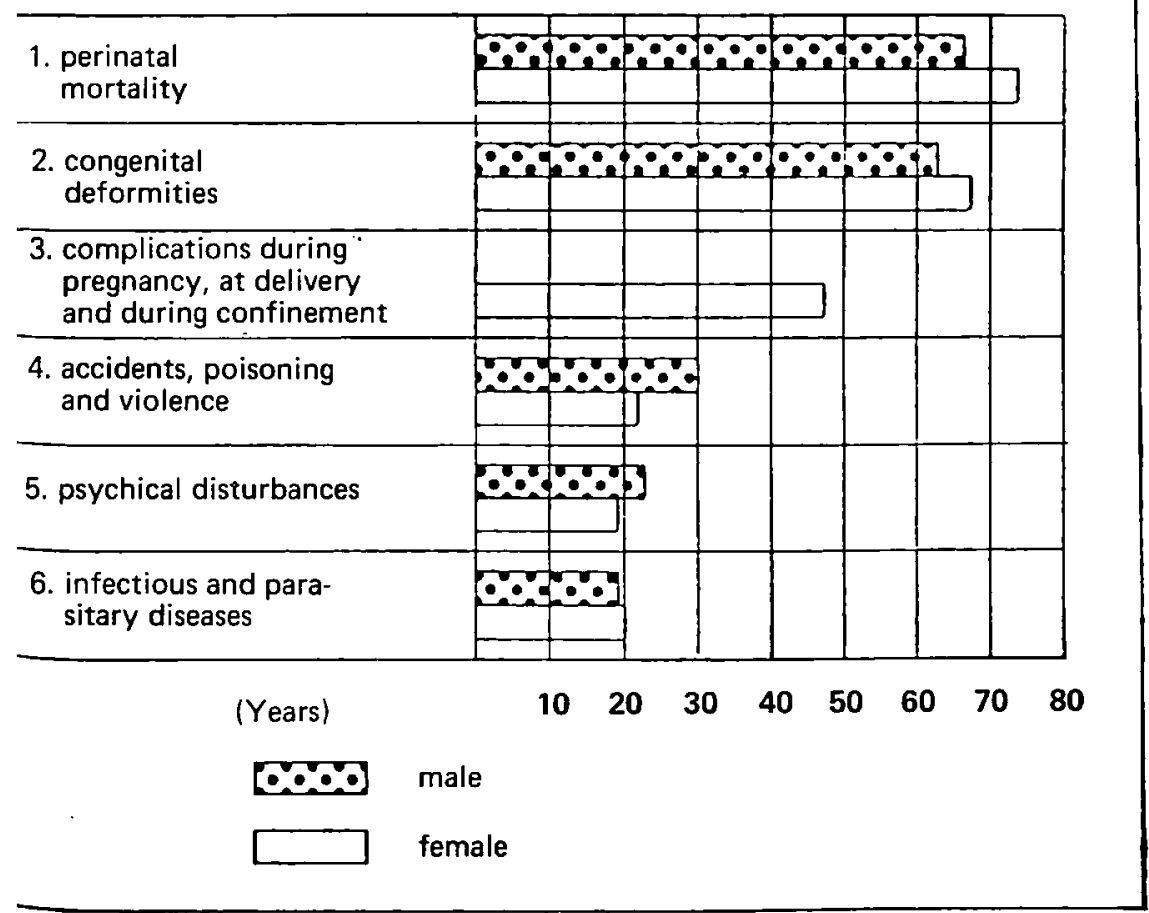

igure 1. Number of lost life years per case of death at early death. Jurce: Henke (1985)

It has been shown that the expenses incurred in an attempt to reduce the social osts of illness caused by "incorrect" hehaviour would not be slight. Thus, it may e that - in fact - the overall social costs of bad health status are very small, and ie real problem is the unequal distribution of opportunities to become more ealthy. 
The answer to the question "Would an increase in sport activities reduce the monetary costs of illness and death?" is again more complicated, because it is not obvious that an overal better health status would reduce the expenditure of health care goods and services. It is obvious that these expenditures increase with the age of people (cf. Becker 1985; Zollmann und Brennecke 1984). One might argue that this phenomenon would disappear if people were healthier due to sport activities. But, it is known that the present supply structures of the health care system tend to induce the demand for their goods and services. This is one reason why a better health status and a longer life span could result in higher expenditure costs for health care. The other reason is that due to the competing risk problem, it is possible that the morbiditiy of people, who gain life years by sport activities, would increase (cf. Dinkel 1986).

\section{Conclusion}

To summarize the theoretical, statistical and empirical results of this paper, it is clear that we do not know much about the relation of sport, health and costs of illness and death in a quantitative manner. To learn more about the epidemiological effects, it would be necessary to collect experimental longitudinal data and thereby control the effects of sport practiced for instrumental reasons. But even better epidemiological figures would not tell us the whole story about the costs of illness. This is due to the fact that another empirical, but psychological question arises: To what extent do we accept on a voluntary basis a probability of death?

The present empirical evidence indicates that in our world, which is not perfect in many senses, the efficient instrument of a bonus system recompensating activities improving the health status would be unfair in the distributional dimension. On the basis of present medical and epidemiological knowledge, the actuarial fair instrument of ex ante premium differentiation would be inefficient.

Finally, one might come to the conclusion that trials to set incentives for behavior which leads to better health could result on the one hand in a small decrease in social costs which might be distributed unequally and would not be observed. On the other hand, those monetary costs for health care expenditure, which are easily observable and considered to be a burden, might increase if sport were an inefficient instrument to become more healthy and live a little bit longer.

\section{Notes}

${ }^{1}$ A detailed version of this paper is published as discussion paper No. 112 of the "Wirtschaftswissenschaftliche Dokumentation" of the Technical University of Berlin (West) (cf. Wagner 1986). In this longer version extensive references are made to the relevant German literature.

${ }_{2}^{2}$ There are considerable differences between urban and rural areas etc; only the possibilities for jogging may be distributed equal between areas.

${ }^{3}$ Unobserved variables which are not orthogonal to the observed variables. The problem of unobserved heterogenity causes instable coefficients of estimates, e.g. of regression coefficients. On the basis of a new test Hausmann (1978) states empirical evidence (for the 
xplanation of earnings) that this problem of misspecification holds true even if we use ongitudinal data which allow for the control of unobserved variables, which are constant ver time.

\section{References}

ITKINSON, A. B. and J. L. TOWNSEND (1977): Economic Aspects of Reduced Smoking. The Lancet, No. 3, p. 492-494

3ECKER, I. (1985): Einkommensumverteilung im Rahmen der gesetzlichen Krankenversicherung. In: W. Schmähl (Ed.), Versicherungsprinzip und soziale Sicherung, Tübingen, p. 98-119

3ROOME, J. (1985): The Economic Value of Life. Economica, Vol. 52, p. 281-294

OASE, R. H. (1961): The Problem of Social Cost. The Journal of Law and Economics, Vol. 3, p. 1-41

JAGANZO, W. (1979): Mulitnomial Probit, New York

INKEL, R. (1986): Mortalitätsindikatoren und ihre Eignung zur Beurteilung der Effizienz von Gesundheitsmaßnahmen. In: Gäfgen, G. (Ed.), Ökonomik des Gesundheitswesens, Berlin

)ÜRRWÄCHTER, H. (1985): Hohe Kosten sparen durch Sport - Wichtiger Verbündeter der Versicherungen / Mängel in der Sportförderung. In: Deutscher Sportbund, DSBInformation, No. 8, 26.2.1985

jALLER, H. P. and G. WAGNER (1983): Arbeitszeitverkürzung und Arbeitsangebot. Wirtschaftsdienst, Vol. 63, No. 7, p. 329-336

jROSSMAN, Michael (1972): On the Concept of Health Capital and the Demand for Health. Journal of Political Economy, Vol. 80, No. 2, p. 223-255, more detailed in: M. Grossman, The Demand for Health, New York, 1972

IAUSMAN, J. A. (1978): Specification Tests in Econometrics. Econometrica, Vol. 46, p. $1251-1271$

IECKMAN, J. J. (1979): Sample Selection Bias as a Specification Error. Econometrica, Vol. 47. No. 1, p. 153-161

IENKE, K.-D. (1985): Die Kosten von Krankheiten - Ein Maßstab für neue Ansätze in der Gesundheitspolitik?. In: H. Milde and H. G. Monissen (Ed.), Rationale Wirtschaftspolitik in komplexen Gesellschaften, Stuttgart et al., p. 412-420

IODGSON, T. A. (1983): The State of the Art of Cost-of-Illness Estimates. Health Economics and Health Services Research, Vol. 4, p. 129-164

IOLLMANN, W. et al (1985): Präventive Kardiologie - Bewegungsmangel und körperliches Training aus epidemiologischer und experimenteller Sicht. Zeitschrift für Kardiologie, Vol. 74, p. 46-54

.ENK, H. (1985): Die achte Kunst - Leistungssport - Breitensport, Zürich

EU, R. E. und T. SCHAUB (1984): Does Smoking Increase Medical Care Expenditure?. Social Science Medicine

ICKENZIE, R. und G. TULLOCK (1978): The New World of Economics - Explorations into the Human Experience, Homewood, Ill.

1ELLEROWICZ, H. und H. DÜRRWÄCHTER (1983): Sport - Gesundheit Wirtschaft - Zusammenhänge und Folgerungen für das derzeitige Gesundheits- und Krankheitswesen. Arbeitsmedizin, Sozialmedizin, Präventivmedizin, 18. Vol., p. 106111

AFFENBARGER, R. S. et al. (1986): Physical Activity, All-Cause-Mortality, and Longevity of College Alumni. New England Journal of Medicine, Vol. 314, No. 10, p. 605-613

AULY, M. V. (1986): Taxation, Health Insurance, and Market Failure in the Medical Economy. Journal of Economic Literature, Vol. XXIV, p. 627-629

ELZMANN, L. (1985): Wirtschaftspsychologie, Wien, New York 
POMMEREHNE, W. W. und B. S., FREY (1985): Kunst - Was sagt der Ökonom dazu?. Schweizerische Zeitschrift für Volkswirtschaft und Statistik, Vol. 121, No. 2, p. 139-167

PROEBSTING, H. (1984): Entwicklung der Sterblichkeit. Wirtschaft und Statistik, No. 1, p. 13-24

RITTNER. V. (1985): Sport und Gesundheit - Zur Ausdifferenzierung des Gesundheitsmotivs im Sport. Die Sportwissenschaft, p. 136-154

SCHNOCKS, H. (1985): Grenzen und Möglichkeiten der Prävention in der Gesundheitserziehung. In: R. ROSENBROCK und F. HAUSS (Ed.): Krankenkassen und Prävention, Berlin, p. 117-124

STOCKES, J. (1983): Why Not Rate Health and Life Insurance Premiums by Risks?. The New England Journal of Medicine, Vol. 308, No. 7, p. 393-395

VALLIN, J. (1980): Socio-economic Determinants of Mortality in Industrialized Countries. Population Bulletin of the United States, No. 13, p. 16-41

VAUPEL, J. W. and A. I. YASHIN (1985): The Deviant Dynamics of Death in Heterogeneous Populations. Sociological Methodology, p. 179-211

VICKREY, C. (1977): The Time-Pour: A New York at Poverty. Journal of Human Resources, Vol. 12, No. 1, p. 27-48

WAGNER, G. (1984): Umverteilung in der gesetzlichen Rentenversicherung, Frankfurt, New York

WAGNER, G. (1986): Sport für alle! Gesundheit für alle, die nichts kostet? Discussion Paper No. 112, Wirtschaftswissenschaftliche Dokumentation, Technical University, Berlin

WASER, O. and P. ZWEIFEL (1986): Innovation in Health Insurance - Bonus Systems in Western Germany. In: M.G.v.d. SCHULENBURG (Ed.), Essays in Social Securily Economics, Berlin et al. p. 169-195

ZOLLMANN, P. und R. BRENNECKE (1984): Ein Zwei-Stufen-Ansatz zur Schätzung der Inanspruchnahme ambulanter ärztlicher Leistungen, Sfb-Working Paper No. 137. Frankfurt, Mannheim

\section{Le sport comme moyen pour réduire les frais de santé - des observations empiriques, statistiques et théorétiques}

Résumé

Dans le mouvement du sport de l'Allemagne Fédérale, souvent la thèse est évoquée que le sport signifierait une voie efficiente et effective pour réduire les "frais de santé". En se basant sur des ébauches théoriques de l'économie sanitaire et d'une évidence empirique correspondante, il est démontré ici, par contre, que le sport n'est pas un instrument adéquate pour réduire des "frais de santé". Il n'est pas certain que faire du sport par prévention soit un succès individuel; les frais opportuns du temps y consacré sont repartis d'une manière socialement inégale et finalement il est très peu probable, d'après la situation acutelle, qu'un meilleur état de santé diminuerait les dépens pour le régime sanitaire. Afin de pouvoir faire des éconcés plus précis au sujet des liaisons d'effet significatives il faudrail des études longitudinales prospectives. 
Sport als Mittel zur Reduzierung der Gesundheitskosten - einige theoretische, statistische und empirische Anmerkungen

\section{Zusammenfassung}

In der Deutschen Sportbewegung wird vielfach die These vertreten, daß Sport einen effektiven und effizienten Weg zur Reduzierung von „Gesundheitskosten“ darstellen würde. Auf Basis gesundheitsökonomischer Theorieansätze und entsprechender empirischer Evidenz wird demgegenüber hier gezeigt, daß Sport kein geeignetes Instrument zur Reduzierung von „Gesundheitskosten“ darstellt. Der individuelle Erfolg von präventivem Sporttreiben ist unsicher; die Opportunitätskosten der dazu aufgewandten Zeit sind sozial ungleich verteilt und schließlich spricht gegenwärtig nur wenig dafür, daß ein besserer Gesundheitszustand die Ausgaben für das Gesundheitswesen senken würde. Um genauere Aussagen zu den relevanten Wirkungsketten machen zu können, wären prospektive Longitudinalstudien notwendig.

\section{EI Deporte como Medio para Reducir los Costes de Enfermedad - Observaciones teóricas, estadísticas y empíricas}

\section{Resumen}

En el Movimiento Deportivo Alemán (Deutsche Sportbewegung) a menudo se sostiene la tesis que el deporte es un camino efectivo y eficiente para reducir los "costes de salud". En este estudio se muestra, basándose en teorías económicas, que el deporte no es un medio apropiado para la reducción de "costes de salud". El éxito individual del deporte preventivo es inseguro; los costes de oportunidad del tiempo invertido están distribuidos de forma dispareja y, finalmente, hay poca probabilidad que un estado de salud mejor reduzca los gastos para los servicios de salud. Para aprender más sobre cadenas de acción importantes se necesitarían estudios longitudinales. 


\section{医譄䩀能減の手段としてのスポーッ}

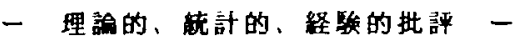

$<$ 抄䎑 $>$

西ドイッにおいては、スポーツ皆及連動に関わる多くの支持者が、スボーツは病公

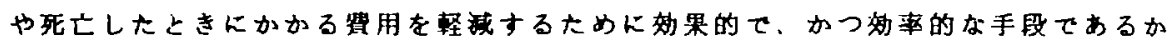
もしれないと提起している。本論では、スポーツが必ずしも堅用能琙の大めのすぐ

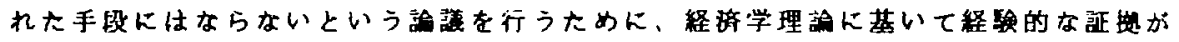
示されている。第一の理由は、手段的に使わ机るスボーッがちぐてのケースにおい て、より良い健康を尊くことができないということである。第二の理由は、スボー ツを実施するための贯用が、不平等に分け与元られているということである。第三

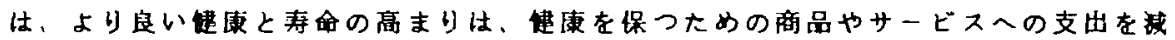
らさことにはなりえないのである。手段的スポーツと链康の度学的関係についてさ らに研究するためには、賈の高いデータが必要であろう。

Спорт как средство уменышения расходов, связанных со здравоохранением. Теоретические, статистические и эмпирические наблюдения.

\section{Pезюме :}

В германском спортивном движении часто Утверждают, что спорт представляет собой эффективный и действенный способ ұменьшения расходов здравоохранения. Однако на основе зкономических теорий и ясных эмпиричных данных можно показать, что спорт нельзя считать подходящим средством уменьшения затрат в целях здравоохранения. Ненадёжен индивидуальный дспех превентивной спортивной деятельности, денежные затраты, связанные со спортивными занятиями неодинаковые и наконец нельзя утверхдать, что хорошее состояние здоровья и продолхительность жизни понизят расходы пля здравоохранения. Чтобы добиться точных высказываний об зпидемиологических соединительных звеньях необходимо провести долговременные исследования. 